\title{
Mercury Redox Chemistry in Waters of the Eastern Asian Seas: From Polluted Coast to Clean Open Ocean
}

\author{
Zhijia Ci, ${ }^{* \dagger}$ Xiaoshan Zhang, ${ }^{\dagger}$ Yongguang Yin, ${ }^{\dagger}$ Jinsheng Chen, ${ }^{\dagger}$ and Shiwei Wang ${ }^{\S}$ \\ ${ }^{\dagger}$ Research Center for Eco-Environmental Sciences, Chinese Academy of Sciences, Beijing, 100085, China \\ ${ }^{\ddagger}$ Key Lab of Urban Environment and Health, Institute of Urban Environment, Chinese Academy of Sciences, Xiamen, 361021, China \\ ${ }^{\S}$ Institute of Oceanology, Chinese Academy of Sciences, Qingdao, 266071, China
}

\section{Supporting Information}

ABSTRACT: We performed incubation experiments using seawaters from representative marine environments of the eastern Asian seas to determine the mercury $(\mathrm{Hg})$ available for photoreduction $(\mathrm{Hgr}(\mathrm{II}))$, to investigate the $\mathrm{Hg}$ redox reaction kinetics, and to explore the effect of environmental factors and water chemistry on the $\mathrm{Hg}$ redox chemistry. Results show that $\mathrm{Hgr}(\mathrm{II})$ accounted for a considerable fraction of total $\mathrm{Hg}$ ( $\mathrm{THg})(\% \mathrm{Hgr}$ (II)/THg: 24.90 $\pm 10.55 \%, n=27$ ) and positively correlated with $\mathrm{THg}$. Filtration decreased the Hgr(II) pool of waters with high suspended particulate matter (SPM). The positive linear relationships were found between pseudo-first order rate constants of gross $\mathrm{Hg}$ (II) photoreduction $\left(k_{\mathrm{r}}\right)$ and gross $\mathrm{Hg}(0)$ photo-oxidation $\left(k_{\mathrm{o}}\right)$ with photosynthetically active radiation (PAR). Under the condition of PAR of $1 \mathrm{~m} \mathrm{~mol} \mathrm{~m}^{-2} \mathrm{~s}^{-1}$, the $k_{\mathrm{r}}$ were significantly $(p<0.05)$ lower than $k_{\mathrm{o}}$ $\left(k_{\mathrm{r}} / k_{\mathrm{o}}: 0.86 \pm 0.22\right)$. The $\mathrm{Hg}(0)$ dark oxidation were significantly higher than the $\mathrm{Hg}$ (II) dark reduction. The $\mathrm{Hg}$ (II) dark reduction was positively correlated to $\mathrm{THg}$, and the anaerobic condition favored the $\mathrm{Hg}$ (II) dark reduction. Filtration significantly influenced the $\mathrm{Hg}$ photoredox chemistry of waters with high SPM. UVB radiation was important for both

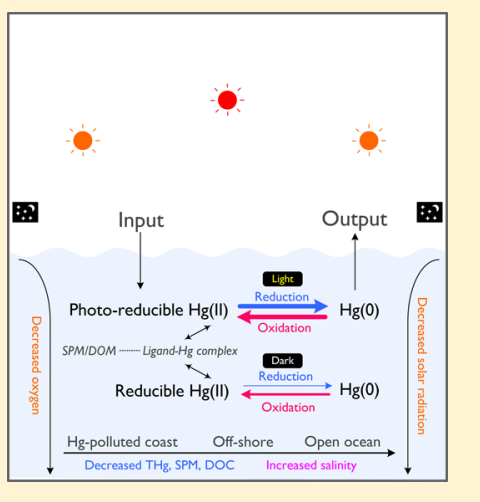
$\mathrm{Hg}$ (II) photoreduction and $\mathrm{Hg}(0)$ photo-oxidation, and the role of other wavebands in photoinduced transformations of $\mathrm{Hg}$ varied with the water chemistry.

\section{INTRODUCTION}

The marine ecosystem plays an important role in global $\mathrm{Hg}$ biogeochemical cycle. ${ }^{1,2}$ Globally, atmospheric deposition of divalent $\mathrm{Hg}(\mathrm{Hg}(\mathrm{II}))$ was determined to be the primary pathway for $\mathrm{Hg}$ input to the ocean. ${ }^{3} \mathrm{Hg}$ (II) in seawaters can be reduced to $\mathrm{Hg}(0)$, which tends to emit to overlying air due to its high volatility. ${ }^{3}$ This process lowers the $\mathrm{Hg}$ loading in marine ecosystems and promotes the redistribution of $\mathrm{Hg}$ in the global environment. ${ }^{1,2}$ In previous studies, researchers thought that $\mathrm{Hg}(0)$ was unreactive in aquatic environments. However, in the past decade, many studies have confirmed that $\mathrm{Hg}(0)$ can be oxidized to $\mathrm{Hg}(\mathrm{II})$ rapidly in salt waters. ${ }^{4-6}$ $\mathrm{Hg}(0)$ oxidation potentially reduces $\mathrm{Hg}(0)$ emissions from marine systems, thus enhances $\mathrm{Hg}$ residence times in waters and increases its potential to enter the food chain. Therefore, $\mathrm{Hg}(\mathrm{II})$ reduction and $\mathrm{Hg}(0)$ oxidation (known as $\mathrm{Hg}$ redox reactions) are important processes that influence the distribution, transport, and toxicological effects of $\mathrm{Hg}$ in marine ecosystems. $^{1-3}$

Over the past several decades, many efforts have been made to explore the mechanisms involved in the $\mathrm{Hg}$ redox chemistry. ${ }^{2}$ Experimentally determined rate constants of $\mathrm{Hg}$ (II) reduction and $\operatorname{Hg}(0)$ oxidation in seawaters have been sporadically reported in the coast, estuary, offshore ${ }^{4-9}$ and open ocean. ${ }^{10,11}$ Studies show that $\mathrm{Hg}(\mathrm{II})$ reduction and $\mathrm{Hg}(0)$ oxidation in aquatic environments can be both photochemically and microbially mediated. ${ }^{12,13} \mathrm{Hg}$ redox reactions in aquatic environments are synergistically controlled by concentrations and speciation of $\mathrm{Hg}$, intensity and wavebands of radiation, concentrations and structure of dissolved organic carbon (DOC), and other physical, chemical, and biological properties of waters (salinity, suspended particulate matter (SPM), dissolved ions, microbial activity, and so on). ${ }^{4-35}$ Therefore, a wide range of rate constants of $\mathrm{Hg}$ (II) reduction and $\mathrm{Hg}(0)$ oxidation have been reported. ${ }^{36}$

As a key component of the regional and global $\mathrm{Hg}$ research framework, model study is an important tool for understanding the global $\mathrm{Hg}$ cycle. ${ }^{1,3}$ One of the most important knowledge gaps of current $\mathrm{Hg}$ model study is the lack of representative and comprehensive kinetic data of $\mathrm{Hg}$ redox reactions in seawaters. ${ }^{1}$ The early models used empirically parametrized rate constants of $\mathrm{Hg}$ redox reactions to match observations. ${ }^{1}$ Recently, modelers began to develop the parametrizations of $\mathrm{Hg}$ redox reactions based on the results of incubation experiments. ${ }^{37,38}$ However, previous incubation studies were performed either with a limited number of water samples or under certain welldefined, but not necessarily environment relevant conditions. $^{4-6,8,10,39}$ This indicates that the data of these studies do

Received: November 4, 2015

Revised: January 20, 2016

Accepted: January 29, 2016

Published: February 10, 2016 
not fully represent the characteristics of the global ocean and meet the need of $\mathrm{Hg}$ model.

In this study, we collected a number of seawaters from representative marine environments of the eastern Asian seas (from Hg-polluted coast to offshore and clean open ocean) to conduct a series of incubation experiments under conditions close to the real environment to explore the $\mathrm{Hg}$ redox chemistry. The goal of this study was (i) to determine the mass and fraction of $\mathrm{Hg}$ that was available for photoreduction; (ii) to investigate rate constants of $\mathrm{Hg}$ (II) reduction and $\mathrm{Hg}(0)$ oxidation; and (iii) to explore the effect of environmental factors (intensity and wavebands of solar radiation) and water chemistry (salinity, SPM, oxygen content, and DOC) on the $\mathrm{Hg}$ redox reactions.

\section{MATERIALS AND METHODS}

2.1. Samples and Instruments. In this study, 27 water samples were collected from the coasts, offshore and open ocean of the eastern Asian seas for incubation experiments. The sampling locations are illustrated in Figure 1. The coastal water

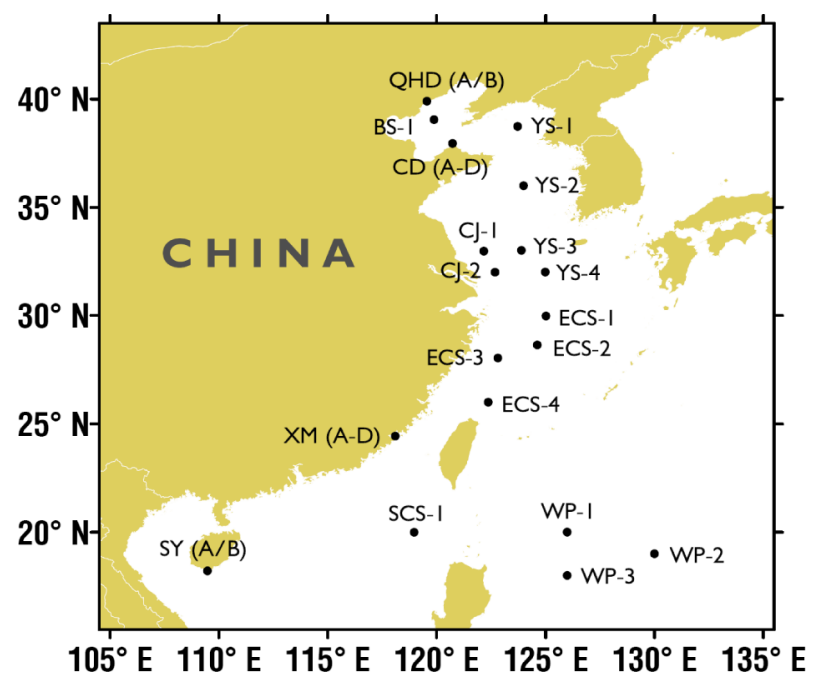

Figure 1. Sampling locations of 27 water samples in the eastern Asian seas. QHD (the coast of Qinghuangdao City), BS (the Bohai Sea), YS (the Yellow Sea), CD (the coast of Changdao Country), CJ (Changjiang Diluted Water), ECS (East China Sea), XM (the coast of Xiamen City), SCS (South China Sea), SY (the coast of Sanya City), WP (the West Pacific Ocean).

samples were manually collected into preclean $4 \mathrm{~L}$ brown borosilicate glass bottles. The surface water $(\sim 1 \mathrm{~m})$ samples from offshore and open ocean were collected with the sampling system consisting of Teflon lined Go-Flo bottles on R/V Kexue 1, Dongfanghong II, and Beidou and quickly decanted into $4 \mathrm{~L}$ acid-cleaned brown glass bottles for preservation and shipped to laboratory and kept in the dark until the time of experiments.

The preclean custom quartz bubblers $(6 \mathrm{~cm}$ OD, $5.5 \mathrm{~cm}$ i.d., $10 \mathrm{~cm}$ height, a longitudinal section of $55 \mathrm{~cm}^{2}$, approximately $160 \mathrm{~mL}$ in volume) were used as the vessel in incubation experiments. The structure of the quartz bubbler was almost identical to that of the Brooks Rand bubbler (08211, Brooks Rand), but all parts of the bubbler (including bottle, stopper, and bubbling frit) were made of quartz glass. The quartz glass is a suitable material for incubation experiments to explore the aquatic $\mathrm{Hg}$ photochemistry because of its high and identical $(\sim 85 \%)$ transmission of the radiation of $200-800 \mathrm{~nm}$ (see
Supporting Information (SI) Figure S1 for more details) and no $\mathrm{Hg}$ loss through the wall. ${ }^{40}$ All materials in contact with seawaters and $\operatorname{Hg}(0)$ were preclean quartz glass, Teflon or borosilicate glass.

To investigate the effect of different wavebands of solar radiation on the $\mathrm{Hg}$ photochemistry, UVB and UV filters (3M) were used to wrap quartz bubblers to shield off the corresponding wavebands of solar radiation (see SI Figure S1 for more details).

The gold traps were used to collect $\mathrm{Hg}(0)$ released from waters. $\mathrm{Hg}(0)$ collected on the gold traps was quantified with a cold vapor atomic fluorescence spectrometry (CVAFS, model III, Brooks Rand). ${ }^{41}$

The incubation experiments using coastal waters generally were performed on site within $0.5-14 \mathrm{~h}$ after the water sampling to minimize the effect of storage of waters on transformations of $\mathrm{Hg}$ and the change of other factors. The incubation experiments using offshore and open waters were conducted within two months after water sampling.

2.2. Experimental Concept. A simple reversible reaction for $\mathrm{Hg}$ redox reactions (eq 1) was used to express the $\mathrm{Hg}$ (II) reduction and $\mathrm{Hg}(0)$ oxidation in aquatic environments. $6,10,32$

$$
\operatorname{Hgr}(\mathrm{II})+\text { photo-reductants } \stackrel{h v}{\leftrightarrow} \mathrm{Hg}(0)+\text { photo-oxidants }
$$

where $\mathrm{Hgr}(\mathrm{II})$ refers the $\mathrm{Hg}$ pool that are available for photoreduction in waters. If the $\mathrm{Hg}(0)$ oxidation can be prevented, we can obtain the pseudo-first rate constant of gross $\mathrm{Hg}(\mathrm{II})$ reduction $\left(k_{\mathrm{r}}\right)$ according to eq 2.

$$
\ln \left[\operatorname{Hg}(0)_{\mathrm{t}} / \mathrm{Hg}(0)_{0}\right]=k_{\mathrm{r}} t
$$

where $[\mathrm{Hg}(0)]_{\mathrm{t}}$ and $[\mathrm{Hg}(0)]_{0}$ represent $\mathrm{Hg}(0)$ concentrations at time $t$ and at the beginning of the incubation experiment, respectively. $k_{\mathrm{r}}$ is the pseudo-first order rate constant of gross $\mathrm{Hg}$ (II) reduction. Similarly, if the $\mathrm{Hg}$ (II) reduction can be prevented, then the pseudo-first rate constant of gross $\mathrm{Hg}(0)$ oxidation $\left(k_{\mathrm{o}}\right)$ can be calculated.

According to eq $1, \operatorname{Hgr}(\mathrm{II})$ is equal to the total $\operatorname{Hg}(0)$ released from the waters until cumulative released $\mathrm{Hg}(0)$ reaches a plateau in full solar radiation if the $\mathrm{Hg}(0)$ oxidation is prevented.

2.3. Experimental Design. 2.3.1. $\mathrm{Hgr}(\mathrm{II})$ and $\mathrm{Hgr}(\mathrm{II}) / \mathrm{THg}$. In a typical incubation experiment for determining the $\mathrm{Hgr}$ (II) pool, aliquots $(150 \mathrm{~mL})$ of water sample in triplicate were distributed to quartz bubblers for incubation from the morning of a cloudless day. Before the incubation experiment, the waters were purged with $\mathrm{Hg}$-free air $\left(\mathrm{Hg}<0.01 \mathrm{pg} \mathrm{L}^{-1}\right)$ in the dark with the flow rate of $0.5 \mathrm{~L} \mathrm{~min}^{-1}$ to remove the natural $\mathrm{Hg}(0)$. After exposed to the solar radiation, the formed $\mathrm{Hg}(0)$ in waters was removed continuously by purging to prevent the $\mathrm{Hg}(0)$ reoxidation. ${ }^{30,42}$ The released $\mathrm{Hg}(0)$ was collected on gold traps with $0.5-1.5 \mathrm{~h}$ interval until the cumulative $\mathrm{Hg}(0)$ reached a plateau. Then the total $\mathrm{Hg}(0)$ released was equal to the amount of $\operatorname{Hgr}(\mathrm{II})$. Our data showed that the released $\mathrm{Hg}(0)$ in all incubated samples reached a plateau after approximately $12-27 \mathrm{~mol} \mathrm{~m}^{-2}$ of cumulative photosynthetically active radiation (PAR). These cumulative PAR were lower than the daily cumulative PAR on experiment days $(\sim 35-42$ mol $\mathrm{m}^{-2}$ ), indicating that the $\mathrm{Hg}(\mathrm{II})$ photoreduction completed in one experiment day.

After the incubation experiment for determining $\operatorname{Hgr}(\mathrm{II})$, the subsamples were transferred to new $50 \mathrm{~mL}$ Falcon poly- 
Table 1. Chemical Variables, $\mathrm{Hg}$ Available for Photoreduction, and the Rate Constants of Divalent $\mathrm{Hg}$ (Hg(II)) Reduction and Elemental $\mathrm{Hg}(\mathrm{Hg}(0))$ Oxidation for Water Samples Collected from Representative Marine Environments of the Eastern Asian Seas

\begin{tabular}{|c|c|c|c|c|c|c|c|c|c|c|c|c|}
\hline $\begin{array}{c}\text { sample } \\
\text { no. }\end{array}$ & $\begin{array}{c}\text { DOC } \\
(\mathrm{mg} \\
\left.\mathrm{L}^{-1}\right)\end{array}$ & $\begin{array}{l}\text { salinity } \\
\text { (PSU) }\end{array}$ & $\begin{array}{l}\text { SPM } \\
(\mathrm{mg} \\
\left.\mathrm{L}^{-1}\right)\end{array}$ & $\underset{\left.\mathrm{L}^{-1}\right)}{\operatorname{Hgr}(\mathrm{II})^{a}}(\mathrm{ng}$ & $\begin{array}{l}\text { remaining } \\
\text { THg }\left(\text { ng L L }^{-1}\right)\end{array}$ & $\underset{\left.\mathrm{L}^{-1}\right)}{\mathrm{THg}^{b}}$ (ng & $\begin{array}{c}\% \mathrm{Hgr}(\mathrm{II}) / \\
\mathrm{THg}(\%)\end{array}$ & $\begin{array}{c}k_{\mathrm{r}}^{c} \\
\left(\mathrm{~h}^{-1}\right)\end{array}$ & $\begin{array}{c}k_{\mathrm{o}}^{d} \\
\left(\mathrm{~h}^{-1}\right)\end{array}$ & $k_{\mathrm{r}} / k_{\mathrm{o}}$ & $\begin{array}{c}k_{\mathrm{o}} \text { in the } \\
\text { dark }\left(\mathrm{h}^{-1}\right)\end{array}$ & $\begin{array}{l}k_{\mathrm{r}}^{e} \text { in the dark } \\
\left(\mathrm{pg} \mathrm{L}^{-1} \mathrm{~h}^{-1}\right)\end{array}$ \\
\hline QHD-A & 3.11 & 28.4 & 40.2 & $1.36 \pm 0.18^{f}$ & $22.31 \pm 2.69$ & $23.68 \pm 2.88$ & 5.77 & 0.32 & 0.33 & 0.97 & 0.08 & 22.3 \\
\hline QHD-B & 2.49 & 28.4 & 43.2 & $1.30 \pm 0.23$ & $14.34 \pm 3.62$ & $15.64 \pm 3.85$ & 8.33 & & & & & \\
\hline BH-1 & 2.83 & 30.7 & 7.2 & $1.20 \pm 0.19$ & $7.43 \pm 0.69$ & $8.63 \pm 0.88$ & 13.94 & 0.34 & 0.35 & 0.97 & 0.06 & 11.4 \\
\hline CD-A & 3.19 & 27.6 & 19.6 & $0.68 \pm 0.09$ & $3.02 \pm 0.69$ & $3.70 \pm 0.78$ & 18.39 & 0.41 & 0.33 & 1.24 & 0.06 & 4.3 \\
\hline CD-B & 3.02 & 27.8 & 17.6 & $0.87 \pm 0.12$ & $4.12 \pm 0.81$ & $4.99 \pm 0.93$ & 17.38 & & & & & \\
\hline CD-C & 3.49 & 26.6 & 19.5 & $1.13 \pm 0.07$ & $3.97 \pm 0.53$ & $5.10 \pm 0.60$ & 22.17 & & & & & \\
\hline CD-D & 2.99 & 26.8 & 14.3 & $0.74 \pm 0.10$ & $4.36 \pm 0.33$ & $5.10 \pm 0.43$ & 14.47 & 0.34 & 0.36 & 0.94 & 0.05 & 5.2 \\
\hline YS-1 & 2.73 & 31.4 & 7.9 & $0.89 \pm 0.12$ & $6.36 \pm 0.96$ & $7.25 \pm 1.08$ & 12.25 & & & & & \\
\hline YS-2 & 2.35 & 31.9 & 5.3 & $0.42 \pm 0.06$ & $1.49 \pm 0.13$ & $1.90 \pm 0.19$ & 21.80 & 0.30 & 0.41 & 0.73 & 0.09 & \\
\hline YS-3 & 1.89 & 31.0 & 7.3 & $0.35 \pm 0.10$ & $1.27 \pm 0.29$ & $1.62 \pm 0.38$ & 21.78 & & & & & \\
\hline YS-4 & 1.07 & 32.0 & 5.2 & $0.51 \pm 0.07$ & $1.75 \pm 0.26$ & $2.26 \pm 0.33$ & 22.69 & 0.31 & 0.52 & 0.60 & 0.06 & 5.3 \\
\hline CJ-1 & 1.39 & 30.8 & 7.1 & $0.38 \pm 0.10$ & $1.58 \pm 0.33$ & $1.20 \pm 0.42$ & 19.18 & 0.28 & 0.36 & 0.78 & 0.05 & 4.4 \\
\hline $\mathrm{CJ}-2$ & 1.44 & 30.3 & 7.6 & $0.41 \pm 0.10$ & $1.22 \pm 0.41$ & $1.63 \pm 0.51$ & 25.09 & 0.24 & 0.34 & 0.70 & 0.06 & 3.0 \\
\hline ECS-1 & 1.56 & 30.8 & $<0.5$ & $0.38 \pm 0.07$ & $1.09 \pm 0.29$ & $1.47 \pm 0.36$ & 26.06 & & & & & \\
\hline ECS-2 & 1.43 & 31.3 & 1.2 & $0.44 \pm 0.08$ & $1.15 \pm 0.32$ & $1.59 \pm 0.40$ & 27.57 & & & & & \\
\hline ECS-3 & 1.77 & 30.9 & 0.9 & $0.43 \pm 0.06$ & $0.59 \pm 0.17$ & $1.02 \pm 0.24$ & 42.24 & 0.25 & 0.41 & 0.61 & 0.08 & 3.3 \\
\hline ECS-4 & 1.58 & 32.0 & 1.2 & $0.38 \pm 0.09$ & $0.88 \pm 0.20$ & $1.26 \pm 0.29$ & 30.37 & & & & & \\
\hline XM-A & 3.42 & 25.5 & 12.5 & $0.72 \pm 0.06$ & $2.22 \pm 0.89$ & $2.94 \pm 0.95$ & 24.58 & 0.32 & 0.30 & 1.07 & 0.05 & 3.2 \\
\hline XM-B & 3.12 & 25.5 & 13.6 & $0.63 \pm 0.13$ & $2.59 \pm 0.56$ & $3.21 \pm 0.69$ & 19.52 & & & & & \\
\hline XM-C & 3.33 & 25.6 & 17.9 & $0.94 \pm 0.09$ & $3.31 \pm 0.12$ & $4.26 \pm 0.21$ & 22.22 & & & & & \\
\hline XM-D & 2.98 & 25.5 & 20.1 & $1.02 \pm 0.12$ & $2.35 \pm 0.59$ & $3.37 \pm 0.71$ & 30.33 & & & & & \\
\hline SY-A & 2.23 & 30.8 & 2.3 & $0.47 \pm 0.06$ & $1.25 \pm 0.26$ & $1.72 \pm 0.32$ & 27.47 & 0.46 & 0.37 & 1.24 & 0.05 & 3.6 \\
\hline SY-B & 2.09 & 30.7 & 3.6 & $0.50 \pm 0.08$ & $1.16 \pm 0.11$ & $1.66 \pm 0.19$ & 30.14 & & & & & \\
\hline SCS-1 & 1.42 & 31.0 & $<0.5$ & $0.37 \pm 0.06$ & $0.55 \pm 0.31$ & $0.92 \pm 0.37$ & 40.18 & 0.27 & 0.38 & 0.71 & 0.07 & 2.4 \\
\hline WP-1 & 1.65 & 32.4 & $<0.5$ & $0.44 \pm 0.09$ & $0.56 \pm 0.16$ & $1.00 \pm 0.25$ & 44.03 & & & & & \\
\hline WP-2 & 1.4 & 32.2 & $<0.5$ & $0.32 \pm 0.08$ & $0.34 \pm 0.19$ & $0.66 \pm 0.27$ & 48.52 & 0.29 & 0.44 & 0.66 & 0.13 & 2.1 \\
\hline WP-3 & 1.54 & 31.9 & $<0.5$ & $0.36 \pm 0.08$ & $0.65 \pm 0.33$ & $1.01 \pm 0.40$ & 35.82 & & & & & \\
\hline
\end{tabular}

${ }^{a} \mathrm{Hg}$ availably for photoreduction. ${ }^{b} \mathrm{Total} \mathrm{Hg}(\mathrm{THg})=\mathrm{Hgr}(\mathrm{II})+$ remaining THg. ${ }^{c}$ The pseudo-first order rate constant of gross $\mathrm{Hg}(\mathrm{II})$ reduction under the condition of PAR of $1 \mathrm{~m} \mathrm{~mol} \mathrm{~m} \mathrm{~s}^{-1}$. ${ }^{d}$ The pseudo-first order rate constant of gross $\mathrm{Hg}(0)$ oxidation under the condition of PAR of $1 \mathrm{~m}$ mol m${ }^{-2} \mathrm{~s}^{-1}$. ${ }^{e}$ The zero order rate constant of $\mathrm{Hg}(\mathrm{II})$ reduction in the dark. ${ }^{f}$ All numbers following a \pm sign represent the standard deviation of three samples.

propylene tubes, ${ }^{32}$ preserved with $0.4 \%$ (v/v) $12 \mathrm{M}$ trace-metal grade $\mathrm{HCl}$, placed into double bags, kept in the dark for analysis of remaining $\mathrm{Hg}^{41,43}$ The $\% \mathrm{Hgr}(\mathrm{II}) / \mathrm{THg}$ was obtained by $\%$ $\mathrm{Hgr}(\mathrm{II}) /(\mathrm{Hgr}(\mathrm{II})+$ remaining $\mathrm{THg})$.

2.3.2. Rate Constants of Gross $\mathrm{Hg}$ (II) Reduction and $\mathrm{Hg}(\mathrm{O})$ Oxidation. In this study, we designed four different exposure treatments to explore quantitative relationships between rate constants of gross $\mathrm{Hg}(\mathrm{II})$ reduction $\left(k_{\mathrm{r}}\right)$ and $\mathrm{Hg}(0)$ oxidation $\left(k_{\mathrm{o}}\right)$ and the intensity of the solar radiation. The $0 \%, 50 \%$ and $87.5 \%$ and $100 \%$ of effective exposure surfaces of bubblers were wrapped with aluminum foil to obtain $100 \%$ (i.e., the full solar radiation), $50 \%, 12.5 \%$, and $0 \%$ (i.e., the dark condition) exposure treatments to the full solar radiation, respectively. The incubation experiments were conduction at midday (ca. 10:30 to $14: 30$, local time) on cloudless days. Both the theoretical calculation $^{44}$ and our measurements (data no shown) show that the solar radiation is relatively stable at midday on cloudless days because the small change of solar angle and little effect of cloud. We therefore assumed that the solar radiation was kept constant during incubation experiments. The bubblers were upright during incubation. The setup of sample radiation did not significantly influence the radiation reaching samples since all parts of bubblers were made of quartz glass with high solar radiation transmissions and the small change of radiation angle at midday. We used the PAR as the surrogate of full solar radiation since PAR is easily measured and strongly correlated with full solar radiation and UV radiation (UVA and UVB), ${ }^{32}$ although we have known that PAR only represents a portion of full solar radiation to trigger the $\mathrm{Hg}$ photochemistry. ${ }^{4,45,46}$ The rate constants of $\mathrm{Hg}(\mathrm{II})$ photoreduction and $\mathrm{Hg}(0)$ photooxidation obtained directly from incubation experiments were scaled up to the PAR or different waveband of solar radiation according to the solar radiation transmission of quartz glass and UVB and UV filters.

Experiments for determining the $k_{\mathrm{r}}$ was similar to those of Hgr(II). In a typical incubation experiment, for each treatment, aliquots $(150 \mathrm{~mL})$ of water sample in triplicate were distributed to three quartz bubblers. Before the incubation experiment, the waters were purged in the dark to remove the natural $\mathrm{Hg}(0)$ (i.e., $\left.[\operatorname{Hg}(0)]_{0}\right)$. After exposure to the solar radiation, the formed $\mathrm{Hg}(0)$ in waters was removed continuously by purging and collected on the gold trap with $\sim 0.1-0.5 \mathrm{~h}$ interval (i.e., $\left.\left[\mathrm{Hg}(0)_{\mathrm{t}}\right]\right)$. Then the $k_{\mathrm{r}}$ was calculated according to eq 2 .

To determine the $k_{\mathrm{o}}$, we used a gastight syringe to inject $\mathrm{Hg}(0)$-saturated air into seawaters in sealed brown glass bottle to spike the natural seawaters. The bottle was shaken slightly and then the seawaters were delivered to quartz bubblers by a peristaltic pump in short time $(<5 \mathrm{~min}) . \mathrm{Hg}(0)$ concentrations of seawaters in the bubblers at the beginning of the incubation experiment were considered as the final $\mathrm{Hg}(0)$ concentrations 
of seawaters spiked with $\mathrm{Hg}(0)$. The spike concentrations of $\mathrm{Hg}(0)\left(\sim 1.5-3.0 \mathrm{ng} \mathrm{L}^{-1}\right)$ were about $20-100$ times greater than the ambient levels of $\mathrm{Hg}(0)$ in the surface seawaters of the eastern Asian seas and other typical marine environments. ${ }^{47-53}$ For each treatment, aliquots $(150 \mathrm{~mL})$ of seawaters spiked with $\mathrm{Hg}(0)$ were distributed to five quartz bubblers quickly. A bubbler was removed and measured for the remaining $\mathrm{Hg}(0)$ with the interval of $0.1-3 \mathrm{~h}$. The method for calculating the $k_{\mathrm{o}}$ was similar to that of the $k_{\mathrm{r}}$. Theoretically, the rate constants of $\mathrm{Hg}(0)$ oxidation in this study should be reported as the rate constants of net $\mathrm{Hg}(0)$ oxidation since the $\mathrm{Hg}(\mathrm{II})$ reduction and $\mathrm{Hg}(0)$ oxidation occurred simultaneously. ${ }^{30,54}$ However, as mentioned above, the seawaters spiked with $\mathrm{Hg}(0)$ were used to conduct incubation experiments. In the early hours of the incubation experiments, the decrease of $\mathrm{Hg}(0)$ in seawaters dominated by the oxidation of spiked $\operatorname{Hg}(0)$, and the increase of $\mathrm{Hg}(0)$ from the $\mathrm{Hg}(\mathrm{II})$ reduction could be negligible. ${ }^{30,54}$ Therefore, this simplification of the gross $\mathrm{Hg}(0)$ oxidation has little effect on the $k_{\mathrm{o}}$ (because of the relatively high uncertainties of rate constants of $\mathrm{Hg}$ redox reactions in present study) and simplifies interpretations of comparisons of rate constants of $\mathrm{Hg}(\mathrm{II})$ reduction and $\mathrm{Hg}(0)$ oxidation.

To assess the influence of SPM on the $\mathrm{Hg}$ redox chemistry, filtered $(0.45 \mu \mathrm{m})$ waters were used for incubation. To study the influence of $\mathrm{O}_{2}$ content on the $\mathrm{Hg}$ redox chemistry, the waters were purged with $\mathrm{Hg}$-free air and $\mathrm{Hg}$-free Argon to generate aerobic and anaerobic condition, respectively. To explore the effect of the different wavebands of solar radiation on the $\mathrm{Hg}$ photoredox chemistry, the quartz bubblers were wrapped with UVB or UV filters to remove the corresponding wavebands from the full solar radiation.

2.4. Analysis and Measurement. 2.4.1. $\mathrm{Hg}$. The ultratrace $\mathrm{Hg}$ techniques were used to determine the $\mathrm{Hg}(0)$ collected on gold traps and $\mathrm{THg}$ in seawaters. ${ }^{41} \mathrm{Hg}(0)$ collected on gold traps was quantified with CVAFS (model III, Brooks Rand) with the two-stage amalgamations. The determination of $\mathrm{THg}$ in seawaters used the EPA method $1631,{ }^{43}$ following $\mathrm{BrCl}$ oxidation, $\mathrm{SnCl}_{2}$ reduction, two-stage gold amalgamation, thermal release and CVAFS quantification. The method detection limit $(\mathrm{MDL})$ for $\mathrm{Hg}(0)$ on gold traps and $\mathrm{THg}$ in seawaters was $0.3 \mathrm{pg}$ and $0.10 \mathrm{ng} \mathrm{L}^{-1}$, respectively. More details of the ultratrace $\mathrm{Hg}$ techniques and QA/QC for $\mathrm{Hg}$ determination are given in SI and our previous literatures. ${ }^{41,47,48}$

2.4.2. DOC. DOC in filtered $(0.45 \mu \mathrm{m})$ waters were determined with an elemental analyzer (vario TOC select, Elementar, Germany) using the high-temperature catalytic oxidation (HTCO) method. The detection limit is $0.02 \mathrm{mg} \mathrm{L}^{-1}$ with a precision within $2 \%$.

2.4.3. SPM. SPM in waters was determined by filtering a known aliquot $(0.40-2.0 \mathrm{~L})$ of sample through a preweighed $0.45 \mu \mathrm{m}$ pore-size filter, rinsing out the salts with Milli-Q water, and drying before reweighing. ${ }^{41,55}$ The $\mathrm{MDL}$ was $0.5 \mathrm{mg} \mathrm{L}^{-1}$ for a typical volume of $1.0 \mathrm{~L}$.

2.4.4. Salinity. The salinity of water (PSU) collected from the offshore and open oceans was recorded by the rosettemounted conductivity-temperature-depth (CTD) probe. The salinity of coastal waters was determined with the portable conductivity/salinity sensor (DDBJ-350, INESA, China).

2.4.5. Ambient PAR. The ambient $\mathrm{PAR}$ radiation was monitored using the PAR sensor (GLZ-C, TOP, China) with $1-5 \mathrm{~min}$ interval in the unit of $\mathrm{m} \mathrm{mol} \mathrm{m} \mathrm{m}^{-2} \mathrm{~s}^{-1}$.

\section{RESULTS}

3.1. $\operatorname{Hgr}(\mathrm{II})$ and $\mathrm{Hgr}(\mathrm{II}) / \mathrm{THg}$. We collected 27 water samples from representative marine environments of the eastern Asian seas, representing a great gradients of $\mathrm{THg}$ (0.66-23.68 ng L $\left.{ }^{-1}\right)$, salinity (25-33), SPM $(<0.5-102.1 \mathrm{mg}$ $\left.\mathrm{L}^{-1}\right)$, and DOC (1.07-3.49 $\left.\mathrm{mg} \mathrm{L}^{-1}\right)$ (Table 1), to investigate the $\mathrm{Hgr}(\mathrm{II})$ pool and its influencing factors. An example illustrating how to determine the $\mathrm{Hgr}$ (II) pool in seawaters is shown in SI Figure S2. In this study, the considerable amount of $\mathrm{Hg}$ (range: $0.32-1.36 \mathrm{ng} \mathrm{L}^{-1}$, mean $\pm \mathrm{SD}: 0.65 \pm 0.32 \mathrm{ng}$ $\left.\mathrm{L}^{-1}, n=27\right)$ was available for photoreduction. Moreover, the $\mathrm{Hgr}(\mathrm{II})$ pool were positively related to the $\mathrm{THg}$, and a logarithmic increase of $\mathrm{Hg}$ (II) pools with increasing $\mathrm{THg}$ was suitable to fit this relationship (SI Figure S2). The \%Hgr(II)/ $\mathrm{THg}$ varied from $5.8 \%$ to $48.5 \%$ with a mean of $24.9 \pm 10.6 \%$, and was exponentially declined with $\mathrm{THg}$, that is, the high \% $\mathrm{Hgr}(\mathrm{II}) / \mathrm{THg}$ was observed in open ocean waters with low $\mathrm{THg}$ and the low $\% \mathrm{Hgr}(\mathrm{II}) / \mathrm{THg}$ in coastal waters with high $\mathrm{THg}$ (Figure 2). There was a strong positive and significant linear relationship between $\mathrm{Hgr}(\mathrm{II})$ and DOC (SI Figure S4).

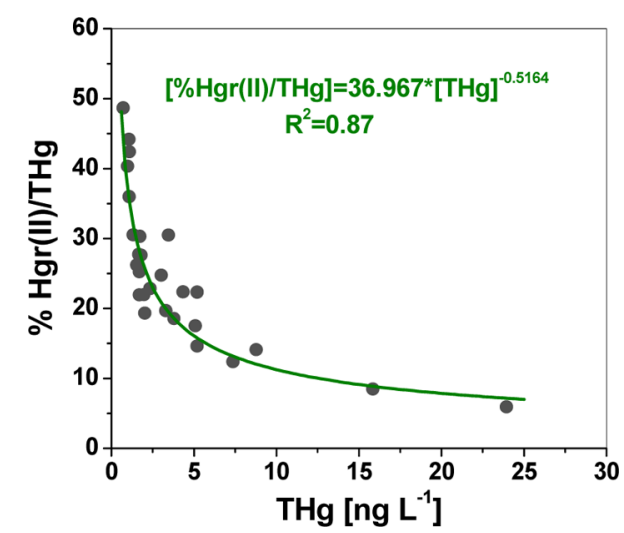

Figure 2. Relationship between \%Hgr(II)/THg and THg in 27 water samples collected from the representative marine environments of the eastern Asian seas.

Three representative coastal water samples, QHD-B, CD-C, and SY-B, were filtered $(0.45 \mu \mathrm{m})$ to explore the effect of SPM on the $\operatorname{Hgr}(\mathrm{II})$ pool. As shown in Figure 3, filtration significantly $(p<0.001)$ decreased THg for all three samples,

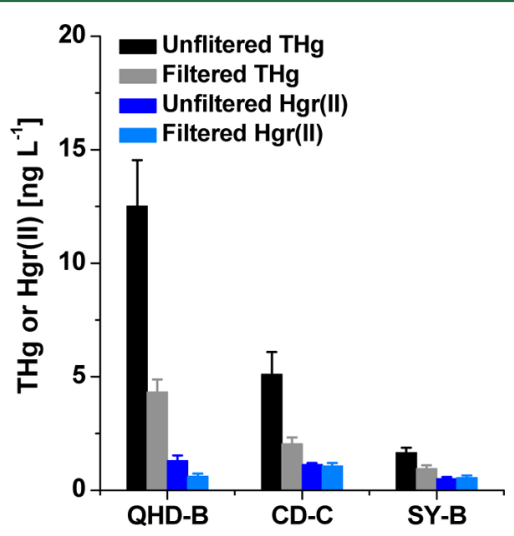

Figure 3. Effect of filtration $(0.45 \mu \mathrm{m})$ on $\mathrm{THg}$ concentrations and Hgr(II) pools for three representative coastal water samples (QHD-B with high SPM and THg, CD-C with moderate SPM and $\mathrm{THg}$, and SY-B with low SPM and THg, see Table 1 for details). 
QHD-B (65.4\%), CD-C (60.0\%), and SY-B (42.8\%). However, $\mathrm{Hgr}(\mathrm{II})$ pools were insignificantly different between filtered and unfiltered waters for CD-C $(p=0.23)$ and SY-B $(p=0.35)$. Only the $\operatorname{Hgr}(\mathrm{II})$ pool of QHD-B significantly $(p<0.001)$ decreased by $52.3 \%$ (from $1.30 \mathrm{ng} \mathrm{L}^{-1}$ to $0.62 \mathrm{ng} \mathrm{L}^{-1}$ ).

3.2. Hg Redox Chemistry. 3.2.1. $\mathrm{Hg}(\mathrm{II})$ Reduction. Thirteen samples were incubated to determine quantitative relationships between the $k_{\mathrm{r}}$ and the PAR intensity. A typical example is shown in SI Figure S5. For all incubated samples $(n$ $=13$ ), simple linear relationships were found to fit the $k_{\mathrm{r}}$ and PAR well with $R^{2}$ ranging between 0.96 and $0.99(p<0.001)$ (see SI Figure S5B, C for a typical example). Because of linear relationships, the slopes of regressions correspond to pseudofirst order rate constants of $\mathrm{Hg}$ (II) reduction under the condition of PAR of $1 \mathrm{~m} \mathrm{~mol} \mathrm{~m} \mathrm{~m}^{-2} \mathrm{~s}^{-1}$ (see SI Figure S5C for example and Table 1 for all data). This method allows comparisons among different treatments, different days and even different studies.

The $k_{\mathrm{r}}$ of 13 samples in full solar radiation at midday varied between 0.32 and $0.62 \mathrm{~h}^{-1}$. The $k_{\mathrm{r}}$ under the condition of PAR of $1 \mathrm{~m} \mathrm{~mol} \mathrm{~m}^{-2} \mathrm{~s}^{-1}$ ranged from 0.24 to $0.46 \mathrm{~h}^{-1}$ with a mean of $0.32 \pm 0.06 \mathrm{~h}^{-1}$ (Table 1 ). There was no significant linear relationship between the $k_{\mathrm{r}}$ under the condition of PAR of $1 \mathrm{~m}$ mol m$~^{-2} \mathrm{~s}^{-1}$ with DOC, salinity and SPM at significant level of 0.05 (SI Figure S6).

Theoretically, the intercepts of regressions correspond to the pseudo-first order rate constant of $\mathrm{Hg}$ (II) reduction in the dark, which varied between 0.002 to $0.015 \mathrm{~h}^{-1}$. We plotted the cumulative $\mathrm{Hg}(0)$ produced during dark reduction incubation experiments versus the duration of incubation time and found strongly positive and significant linear relationships between them. A typical example is shown in SI Figure S7. The assumption of zero order rate constants of gross $\mathrm{Hg}$ (II) reduction in the dark generally leads to a good fit with experimental results. For all 12 incubated seawaters, strongly positive and significant correlations were observed between zero order rate constants of gross $\mathrm{Hg}$ (II) reduction in the dark and $\mathrm{THg}$ (Figure 4). The $\mathrm{Hg}(0)$ production rates $(2-20 \mathrm{pg}$

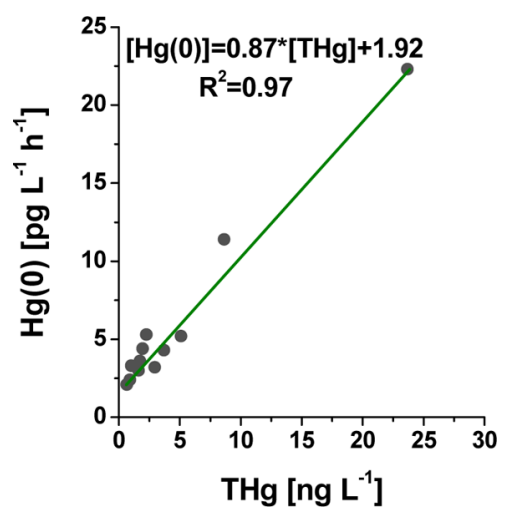

Figure 4. Zero order rate constants of $\mathrm{Hg}$ (II) reduction in the dark $\left(\mathrm{pg} \mathrm{L}^{-1} \mathrm{~h}^{-1}\right)$ versus $\mathrm{THg}$ concentrations in waters. Note that the linear regression was not constrained to pass through the origin.

$\left.\mathrm{L}^{-1} \mathrm{~h}^{-1}\right)$ in the dark were $\sim 10^{2}$ times lower than those in full solar radiation at midday $\left(130-2000 \mathrm{pg} \mathrm{L}^{-1} \mathrm{~h}^{-1}\right)$. Because of the extremely low rate constants of $\mathrm{Hg}$ (II) reduction in the dark compared to those in the light, rate constants of $\mathrm{Hg}$ (II) dark reduction was ignored in the below relative calculations.
Figure 5 shows that the rate constants of $\mathrm{Hg}$ (II) dark reduction of seawaters purged with $\mathrm{Hg}$-free Argon were

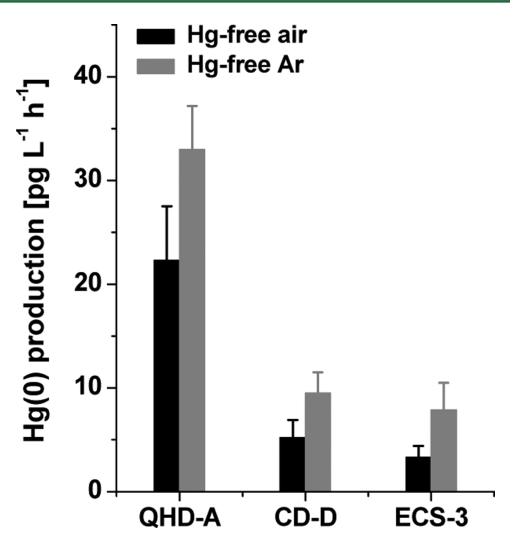

Figure 5. Effect of aerobic ( $\mathrm{Hg}$-free air as the purging gas) and anaerobic ( $\mathrm{Hg}$-free Argon as the purging gas) conditions on the rate of $\mathrm{Hg}(0)$ production in the dark.

significantly $(p<0.05)$ higher than those purged with $\mathrm{Hg}$ free air. The highest increase of rate constants (140\%) was observed in ECS-3, which has the lowest rate constants of $\mathrm{Hg}(\mathrm{II})$ reduction in the aerobic condition.

3.2.2. $\mathrm{Hg}(\mathrm{O})$ Oxidation. Thirteen samples used to determine rate constants of gross $\mathrm{Hg}(\mathrm{II})$ photoreduction were also incubated to determine rate constants of $\mathrm{Hg}(0)$ photooxidation. A typical example is shown in SI Figure S8. The $k_{\mathrm{o}}$ in full solar radiation at midday varied from 0.43 to $0.90 \mathrm{~h}^{-1}$. Simple linear relationship was also found to fit the $k_{\mathrm{o}}$ and PAR well ( $R^{2}$ ranging between 0.97 and $0.99, p<0.001$, see SI Figure S8B, C for a typical example). The slopes of regressions correspond to the $k_{\mathrm{o}}$ under the condition of PAR of $1 \mathrm{~m} \mathrm{~mol}$ $\mathrm{m}^{-2} \mathrm{~s}^{-1}$ (see SI Figure S7C for a typical example). The slopes ranged from 0.30 to $0.52 \mathrm{~h}^{-1}$ with a mean of $0.38 \pm 0.06 \mathrm{~h}^{-1}$ (Table 1). The $k_{\mathrm{o}}$ under the condition of PAR of $1 \mathrm{~m} \mathrm{~mol} \mathrm{~m}^{-2}$ $\mathrm{s}^{-1}$ were found to show a significant and positive correlation with salinity, a significant but negative correlation with DOC, and no significant correlation with SPM (SI Figure S9).

Similarly, the intercepts of linear regressions between the $k_{\mathrm{o}}$ and PAR correspond to the $k_{\mathrm{o}}$ in the dark. These intercepts for all regressions ranged from 0.05 to $0.13 \mathrm{~h}^{-1}$ with a mean of 0.07 $\pm 0.02 \mathrm{~h}^{-1}$ (Table 1$)$, and was not significantly different from the values determined from incubation experiments of $\operatorname{Hg}(0)$ oxidation in the dark $(p=0.453)$. The rate constants of $\mathrm{Hg}(0)$ dark oxidation was positively and significantly correlated with salinity at significant level of 0.10 (SI Figure S10).

3.2.3. The Impact of SPM. The filtered samples of QHD-B, $\mathrm{CD}-\mathrm{C}$ and SY-B were further incubated to explore the impact of SPM on the Hg photoredox chemistry. The data show that for all three samples, filtration significantly $(p<0.001)$ decreased the $\mathrm{Hg}$ (II) dark reduction, QHD-B (77.5\%), CD-C (53.5\%), SY-B (61.3\%), but did not influence the $\mathrm{Hg}(0)$ dark oxidation (Figure 6A, B). Filtration significantly increased the $k_{\mathrm{r}}$ and decreased $k_{\mathrm{o}}$ of QHD-B in the ligh $(p<0.05)$, but did not significantly influence either the $k_{\mathrm{r}}$ or $k_{\mathrm{o}}$ of CD-C $(p=0.23)$ and SY-B $(p=0.16)$ in the light (Figure 6C).

3.2.4. The Impact of Different Wavebands of Solar Radiation. We incubated three representative samples, CD-B (the coast water), ECS-2 (the offshore water), and WP-1 (the open ocean water), to examine the effect of different wavebands of solar radiation on the $\mathrm{Hg}$ photoredox chemistry. For the 

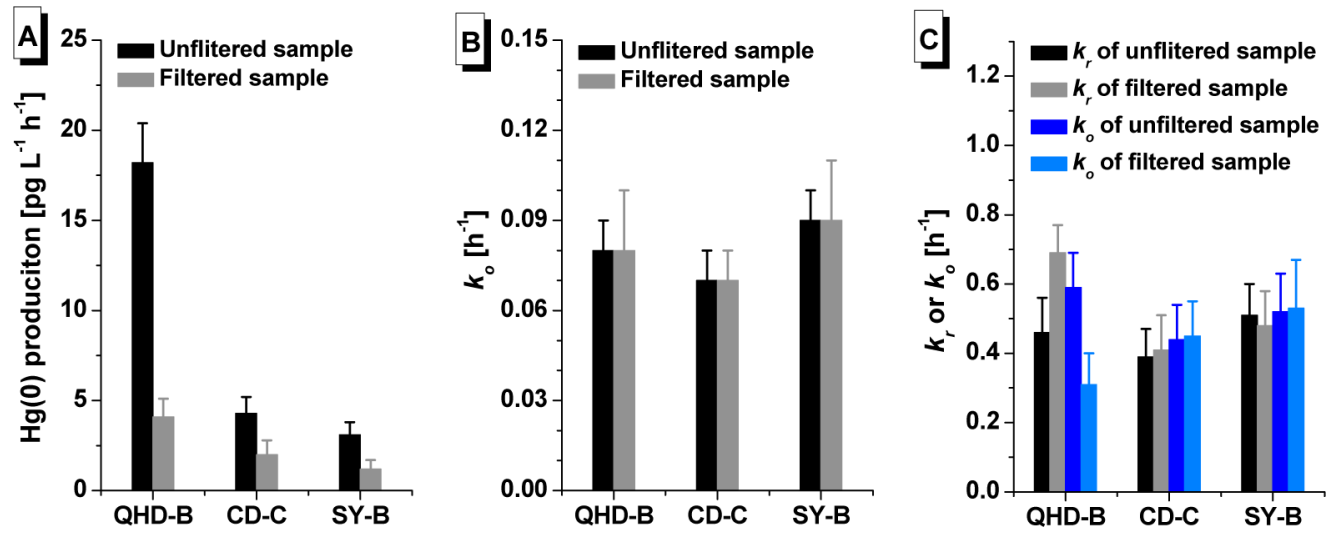

Figure 6. Using three representative coastal water samples (QHD-B with high SPM and THg, CD-C with moderate SPM and THg, and SY-B with low SPM and THg) to investigate the effect of SPM on the Hg redox reactions in the light and dark condition. (A) The effect of filtration on the $\mathrm{Hg}$ (II) dark reduction. (B) The effect of filtration on the pseudo-first order rate constants of gross $\mathrm{Hg}(0)$ dark oxidation. (C) The effect of filtration on the pseudo-first order rate constants of gross $\mathrm{Hg}$ (II) reduction and gross $\mathrm{Hg}(0)$ oxidation in full solar radiation at midday on cloudless days. The incubation experiments for filtered and unfiltered water of each sample were performed at the same time since the PAR intensity has important influence on the $\mathrm{Hg}$ photochemistry (see text).
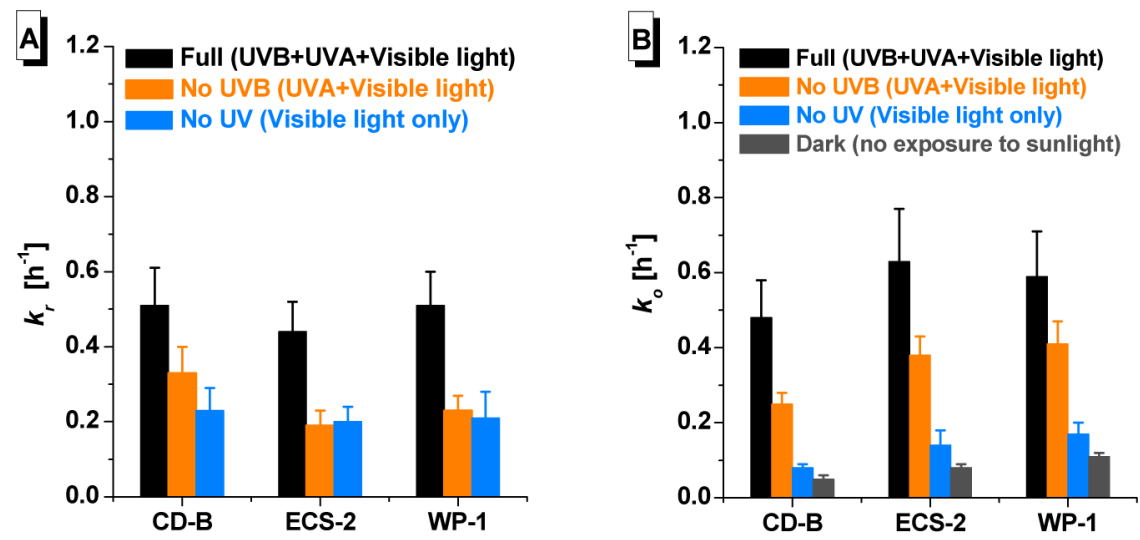

Figure 7. Effect of different wavebands of solar radiation on the $\mathrm{Hg}(\mathrm{II})$ photoreduction and $\mathrm{Hg}(0)$ photo-oxidation for three typical water samples (CD-B with high THg and SPM, ECS-2 with moderate THg and SPM, and WP-1 with low THg and SPM). The incubation experiments included four radiation treatments: full solar radiation (UVB + UVA + visible light), no UVB (UVA + visible light), no UV (visible light only) and dark treatment. (A) The effect of different wavebands of solar radiation on the pseudo-first order rate constants of gross $\mathrm{Hg}$ (II) photoreduction. The rate constants of $\mathrm{Hg}$ (II) dark reduction was extremely low (see text) and the data are not shown. (B) The effect of different wavebands of solar radiation on pseudo-first order rate constants of gross $\mathrm{Hg}(0)$ photo-oxidation at midday.

$\mathrm{Hg}$ (II) photoreduction, UVB radiation accounted for $\sim 30-$ $55 \%$ of full solar radiation for these three samples (Figure $7 \mathrm{~A}$ ). The remaining photoreduction of $\mathrm{Hg}$ (II) mainly mediated by the visible light, except for the sample of $\mathrm{CD}-\mathrm{B}$, in which the UVA radiation contributed to the detectable fraction $(\sim 20 \%)$ of total $\mathrm{Hg}(\mathrm{II})$ photoreduction. For the $\mathrm{Hg}(0)$ photo-oxidation, UVB radiation accounted for $\sim 25-50 \%$ of the full solar radiation (Figure $7 \mathrm{~B}$ ). Different from on the $\mathrm{Hg}$ (II) photoreduction, the contribution of UVA radiation on the $\mathrm{Hg}(0)$ photo-oxidation was comparable to or slightly higher than that of the UVB radiation (Figure 7). For WP-1 with low $\mathrm{THg}$ and SPM, UVA radiation was more important than UVB radiation on the $\mathrm{Hg}(0)$ photo-oxidation. The role of visible light in the $\mathrm{Hg}(0)$ oxidation was not so important, the $\mathrm{Hg}(0)$ oxidation triggered by the visible light were slightly but significantly higher than those in the dark $(p<0.01)$.

\section{DISCUSSION}

It is well-known that some fractions of $\mathrm{Hg}$ in both freshwaters and seawaters can be reduced to form $\mathrm{Hg}(0)$ under natural sunlight or artificial radiation. ${ }^{10}$ However, the focused investigation of $\mathrm{Hgr}(\mathrm{II})$ pool and its controlling factors in seawaters are sparse. In this study, the measurements of waters from representative marine environments of the eastern Asian seas revealed that there was considerable amount of $\mathrm{Hg}$ available for photoreduction. The positive relationships between $\mathrm{Hgr}(\mathrm{II})$ pool and THg (Figure 2 and SI Figure S3) indicate that coastal waters with high $\mathrm{THg}$ had large potentials to produce more $\mathrm{Hg}(0)$ in the light, and high $\% \mathrm{Hgr}(\mathrm{II}) / \mathrm{THg}$ in open ocean waters with low $\mathrm{THg}$ indicates the relatively rapid cycling of $\mathrm{Hg}$ in surface open ocean. The fact that the $\mathrm{Hg}$ in waters with high $\mathrm{THg}$ and SPM was less efficiently photoreduced is possibly subjected to the strong $\mathrm{Hg}$ complexation. ${ }^{56}$ The positive correlations between $\mathrm{Hgr}$ (II) and DOC indicate that the presence of DOC possibly favored the $\mathrm{Hg}$ photoreduction. ${ }^{8}$

It is well documented that $\mathrm{Hg}$ mainly presents in particulate phase in aquatic environments, especially for the waters with high SPM. ${ }^{41,57,58}$ However, the effect of SPM on $\mathrm{Hgr}(\mathrm{II})$ pool is poorly investigated. In this study, as expected, filtration significantly decreased THg (Figure 3). However, the effect of SPM on Hgr(II) pool was more complicated. We found that in 
seawaters with low SPM, $\operatorname{Hgr}(\mathrm{II})$ primarily presented in dissolved phase, but in seawaters with high SPM, Hgr(II) partly presented in particulate phase (Figure 3). It indicates that the involvement of SPM (including organisms and mineral particles) directly or indirectly increased the $\mathrm{Hgr}$ (II) pool or stimulated $\mathrm{Hg}$ (II) photoreduction, $, 22,23,31,59-62$ although our study could not ascertain the threshold of the loadings and chemical or biological compositions of SPM that influence the Hgr(II) pool.

At present, the nature of the photoreducible $\mathrm{Hg}$ (II) in aquatic environments is complex and unknown. Beside of concentrations of $\mathrm{Hg}, \mathrm{SPM}$, and DOC, the Hgr(II) pool may also depend on many other factors, such as the structure of DOC, the concentrations of inorganic ligands, $\mathrm{pH}$, the radiation, and so on. ${ }^{4563}$ Although we reported a relationship between $\mathrm{THg}$ and $\mathrm{Hgr}$ (II), the relationship may be different in other regions and even at different sampling times for the same regions due to the change of water chemistry. Therefore, additional field and laboratory works are required to understand the site-to-site differences in the photoreducible $\mathrm{Hg}$.

In this study, the strongly positive linear relationships between rate constants of $\mathrm{Hg}$ photoredox reactions and solar radiation (PAR was measured as the surrogate of full solar radiation) indicate that the radiation was the dominant factor controlling photoinduced transformations of $\mathrm{Hg}$, which is constant with many other studies. ${ }^{4,10,21,30,64}$ It suggests that the photochemical processes overwhelmingly dominate transformations of $\mathrm{Hg}$ in surface waters of oceans and seas. The rapid transformations of $\mathrm{Hg}$ among different species in the light also highlight that the waters sampled for $\mathrm{Hg}(0)$ determination must be kept in dark prior to analysis.

A direct comparison of rate constants of $\mathrm{Hg}$ photoredox reaction among different experiments is difficult since intensity and wavebands of radiation greatly influence the $\mathrm{Hg}$ photoredox chemistry and most previous studies did not report the detailed information of radiation. Furthermore, many different terms (reaction kinetics, gross reaction kinetics or net reaction kinetics) have been used to report rate constants of $\mathrm{Hg}$ redox reactions in different literatures with various incubation protocols and calculation methods. ${ }^{54}$ Roughly, the rate constants of gross $\mathrm{Hg}(\mathrm{II})$ reduction $\left(0.24-0.46 \mathrm{~h}^{-1}\right)$ at midday in full solar radiation in our study are comparable to previously reported values of salt waters $\left(0.1-1.5 \mathrm{~h}^{-1}\right)^{6,10}$ and freshwaters $\left(0.1-1 h^{-1}\right) .^{32,64}$ The rate constants of gross $\mathrm{Hg}(0)$ oxidation $\left(0.30-0.52 \mathrm{~h}^{-1}\right)$ at midday in full solar radiation were also comparable to other salt waters, ${ }^{6,65,66}$ but were clearly higher $(\sim 5-10$ times) than those of freshwaters, where $\mathrm{Hg}(0)$ oxidation was either not detectable or relatively slow. ${ }^{66,67}$

Because of linear relationships between rate constants of $\mathrm{Hg}$ gross photoredox reactions and PAR intensity, the ratio of $k_{\mathrm{r}} / k_{\mathrm{o}}$ for the same radiation should be more proper to compare the relative importance of $\mathrm{Hg}(\mathrm{II})$ reduction and $\mathrm{Hg}(0)$ oxidation. In our study, the ratios of $k_{\mathrm{r}} / k_{\mathrm{o}}$ under the condition of PAR of 1 $\mathrm{m} \mathrm{mol} \mathrm{m} \mathrm{m}^{-2} \mathrm{~s}^{-1}$ varied from 0.60 to 1.24 with a mean of $0.86 \pm$ $0.22(n=13)$. These ratios were significantly lower than $1(p<$ $0.05)$, indicating that the magnitude of $\mathrm{Hg}(0)$ photo-oxidation was greater than that of $\mathrm{Hg}(\mathrm{II})$ photoreduction in our seawaters. Similar results were also reported by Whalin et al. ${ }^{6}$ with a limited number of coastal waters from the Chesapeake Bay. ${ }^{6}$ Compared to freshwaters with relatively high rate constants of $\mathrm{Hg}(\mathrm{II})$ photoreduction, ${ }^{66,67}$ these ratios further suggest the importance of $\mathrm{Hg}(0)$ oxidation in salt waters. Previous studies suggest that the presence of chloride effectively promotes the $\operatorname{Hg}(0)$ oxidation in salt waters. ${ }^{22,65,66}$ The above discussion highlights that the marine ecosystems are more vulnerable to $\mathrm{Hg}$ contamination compared to freshwater ecosystems since the enhanced oxidative process could greatly increase the $\mathrm{Hg}$ residence time in marine environments.

The effect of DOC on the $\mathrm{Hg}$ redox reactions in aquatic environments may be one of the most challenging issues on the $\mathrm{Hg}$ biogeochemistry. ${ }^{36}$ Our results show that high DOC in seawaters favored the $\mathrm{Hg}$ (II) photoreduction (SI Figure S6) and decreased the $\mathrm{Hg}(0)$ photo-oxidation (SI Figure S9). This finding is consistent with the study of Costa and Liss, ${ }^{8}$ who observed that seawaters spiked with humic acid had enhanced $\mathrm{Hg}$ (II) reduction rates.

The effect of salinity on the $\mathrm{Hg}$ redox reactions seems to be relatively clear. It is well documented that high salinity promotes the $\operatorname{Hg}(0)$ oxidation in aquatic environments. $2,65,66$ We also found that high salinity induced high $k_{\mathrm{o}}$ in the light, and a positive correlation between salinity and the $k_{\mathrm{o}}$ in the dark was also found at significant level of 0.10 (SI Figure S10). This study and many other studies show that the $k_{\mathrm{r}}$ of fresh waters and salt waters in the light are comparable, indicating the salinity does not significantly influence the $\mathrm{Hg}(\mathrm{II})$ photoreduction.

The effect of SPM on the $\mathrm{Hg}$ redox chemistry seems to be more complicated. For all water samples incubated to study the $\mathrm{Hg}$ photoreaction kinetics, no significant correlation was found between the $k_{\mathrm{r}}$ and SPM (SI Figure S6B), and a negative correlation between the $k_{\mathrm{o}}$ and SPM at a significant level of 0.09 (SI Figure S9B). We further incubated filtered waters of three representative coastal waters and found the filtration only influenced the $\mathrm{Hg}$ photoredox chemistry of QHD-B with high SPM (Figure 6). The high $k_{\mathrm{r}}$ of filtered QHD-B in the light was likely caused by the increased light penetration and weak $\mathrm{Hg}$ complexation in dissolved phase. ${ }^{36}$ The decreased $k_{\mathrm{o}}$ of filtered QHD-B in the light probably indicates that $\mathrm{Hg}(0)$ photooxidation occurred heterogeneously. ${ }^{39}$ The decreased rate constants of $\mathrm{Hg}(\mathrm{II})$ dark reduction of filtered waters indicate that the involvement of SPM could promote the $\mathrm{Hg}$ (II) dark reduction. The most likely role of SPM in the $\mathrm{Hg}$ (II) dark reduction was the involvement of organisms since the $\mathrm{Hg}$ (II) dark reduction regulated by the biological process has been extensively identified in marine environments. ${ }^{9,68}$

In our study, the $\mathrm{Hg}(0)$ photo-oxidation was mainly triggered by the UV radiation (UVB and UVA radiation), and the visible light was also significantly contributed to the $\mathrm{Hg}$ (II) photoreduction (Figure 7). Many studies suggest the complicated effect of different wavebands of radiation on the $\mathrm{Hg}$ photoredox chemistry in aquatic environments. ${ }^{4,45,46}$ In most instances of previous studies, the UV radiation was found to significantly promote the $\mathrm{Hg}(\mathrm{II})$ production and $\mathrm{Hg}(0)$ oxidation in both salt and fresh waters. ${ }^{4,46}$ However, $\mathrm{Hg}$ (II) photoreduction in some freshwaters with high DOC could not be triggered by the UVB radiation (e.g., ref 45). The above discussions suggest that the $\mathrm{Hg}$ photoredox chemistry for different water chemistry was sensitive to different wavebands of solar radiation.

The $\mathrm{Hg}(\mathrm{II})$ dark reduction was low but detectable and followed the zero order kinetics (SI Figure S7). The comparable rate constants of $\mathrm{Hg}$ (II) dark reduction were also reported in previous studies. ${ }^{9,69}$ The zero order rate constants of $\mathrm{Hg}(\mathrm{II})$ dark production was positively related to $\mathrm{THg}$ (Figure 4), which is constant with other studies. 9,69 We speculated that the $\mathrm{Hg}(\mathrm{II})$ dark reduction was possibly 
controlled by the chemical and biological mechanisms related to heterogeneous reactions that the SPM involved, such as microbe and mineral particles $7,9,23-31,31,59-62,68$ since filtration significantly decreased the rate constants of $\mathrm{Hg}$ (II) dark reduction (Figure 6A). The rate constants of $\mathrm{Hg}$ (II) dark reduction were enhanced under the anaerobic condition (Figure 5), which is constant with the finding of Beucher. ${ }^{69}$ The above discussions indicate that $\mathrm{Hg}(0)$ can be produced continuously in the entire water column in the oceans throughout the entire day. The findings also highlight the important role of deep seawaters with enhanced $\mathrm{THg}$ (e.g., in coastal and marginal seas) in the marine $\mathrm{Hg}$ biogeochemical cycle since the high $\mathrm{THg}$ in these waters potentially induces the remarkable $\mathrm{Hg}(0)$ production in the dark and anaerobic condition. This finding might explain why the considerable $\mathrm{Hg}(0)$ has been extensively observed in deep waters in some coastal and marginal seas, ${ }^{48,70}$ where the photoreduction was unlikely to play a major role. The results also suggest that the long purging time with $\mathrm{N}_{2}$ or Argon could potentially result in positive artifacts of purgeable $\mathrm{Hg}(0)$ measurements.

In some previous studies, the $\mathrm{Hg}$ (II) dark reduction was not observed in aquatic environments (e.g., ref 22). It is noted that in these experiments, incubated waters were generally not purged continuously to remove the produced $\mathrm{Hg}(0)$. Since the $\mathrm{Hg}(\mathrm{II})$ reduction and $\mathrm{Hg}(0)$ oxidation occur simultaneously in the dark, if the waters used for incubation are kept in the dark for long enough prior to incubation experiments, the $\mathrm{Hg}(0)$ in waters will have reached a plateau, then in the course of dark incubation, the change of $\mathrm{Hg}(0)$ is too little to detect because of the balance of $\mathrm{Hg}(\mathrm{II})$ reduction and $\mathrm{Hg}(0)$ oxidation in the dark.

In this study, rate constants of $\operatorname{Hg}(0)$ dark oxidation were $\sim 10^{2}$ times higher than those of $\mathrm{Hg}$ (II) dark reduction. The rate constants of $\operatorname{Hg}(0)$ dark oxidation were also clearly higher than those of freshwaters. ${ }^{18,66}$ The high rate constants of $\mathrm{Hg}(0)$ dark oxidation in seawaters suggest that the water samples used to determine the $\operatorname{Hg}(0)$ should be purged as soon as possible after sampling. A more recent study suggested that the $\mathrm{Hg}(0)$ might bond to SPM in lake waters, ${ }^{71}$ indicating the rate constants of $\operatorname{Hg}(0)$ dark oxidation obtained from incubation experiments probably have positive artifacts. However, in our study filtration did not significantly influence the $\mathrm{Hg}(0)$ dark oxidation kinetics (Figure 6B). Thus, the phase distribution of $\mathrm{Hg}(0)$ in fresh waters may differ from that in salt waters since freshwaters are generally low in ionic strength and high in alkalinity and DOC. It indicates that the interaction between $\mathrm{Hg}(0)$ and SPM in aquatic environments may be different system-to-system and even site-to-site.

\section{ASSOCIATED CONTENT}

\section{S Supporting Information}

The Supporting Information is available free of charge on the ACS Publications website at DOI: 10.1021/acs.est.5b05372.

Figure S1-S10 and text (PDF)

\section{AUTHOR INFORMATION}

\section{Corresponding Author}

*E-mail: zjci@rcees.ac.cn.

\section{Notes}

The authors declare no competing financial interest.

\section{ACKNOWLEDGMENTS}

This research was funded by the National Key Basic Research Program of China (No. 2013CB430002) and National Natural Science Foundation of China (Nos. 41203068, 41573117, 41176066, and 41371461) and Young Scientists Fund of Research Center for Eco-Environmental Sciences, Chinese Academy of Sciences (No. RCEES-QN-20130048F). We thank Hui Huang and Weihua Zhou (South China Sea Institute of Oceanology, Guangzhou) for their assistance in field experiments. We are grateful for the assistance of the captains and crews of the R/V Kexue I (Institute of Oceanology, Chinese Academy of Sciences), Dongfanghong II (Ocean University of China) and Beidou (Yellow Sea Fisheries Research Institute, Chinese Academy of Fishery Sciences, the Ministry of Agriculture) in the water sampling and data collections. We thank the reviewers for their valuable comments and suggestions.

\section{REFERENCES}

(1) Strode, S. A.; Jaeglé, L.; Selin, N. E.; Jacob, D. J.; Park, R. J.; Yantosca, R. M.; Mason, R. P.; Slemr, F. Air-sea exchange in the global mercury cycle. Global Biogeochem. Cy. 2007, 21, GB1017.

(2) Mason, R. P.; Choi, A. L.; Fitzgerald, W. F.; Hammerschmidt, C. R.; Lamborg, C. H.; Soerensen, A. L.; Sunderland, E. M. Mercury biogeochemical cycling in the ocean and policy implications. Environ. Res. 2012, 119, 101-117.

(3) Mason, R. P.; Sheu, G. R. Role of the ocean in the global mercury cycle. Global Biogeochem. Cy. 2002, 16, 1093.

(4) Amyot, M.; Gill, G. A.; Morel, F. M. M. Production and loss of dissolved gaseous mercury in coastal seawater. Environ. Sci. Technol. 1997, 31, 3606-3611.

(5) Amyot, M.; Morel, F. M. M.; Ariyas, P. A. Dark oxidation of dissolved and liquid elemental mercury in aquatic environments. Environ. Sci. Technol. 2005, 39, 110-114.

(6) Whalin, L.; Kim, E. H.; Mason, R. Factors influencing the oxidation, reduction, methylation and demethylation of mercury species in coastal waters. Mar. Chem. 2007, 107, 278-294.

(7) Baeyens, W.; Leermakers, M. Elemental mercury concentrations and formation rates in the Scheldt estuary and the North Sea. Mar. Chem. 1998, 60, 257-266.

(8) Costa, M.; Liss, P. Photoreduction and evolution of mercury from seawater. Sci. Total Environ. 2000, 261, 125-135.

(9) Fantozzi, L.; Ferrara, R.; Frontini, F. P.; Dini, F. Dissolved gaseous mercury production in the dark: evidence for the fundamental role of bacteria in different types of Mediterranean water bodies. Sci. Total Environ. 2009, 407, 917-924.

(10) Qureshi, A.; O’Driscoll, N. J.; MacLeod, M.; Neuhold, Y. M.; Hungerbühler, $\mathrm{K}$. Photoreactions of mercury in surface ocean water: gross reaction kinetics and possible pathways. Environ. Sci. Technol. 2010, 44, 644-649.

(11) Mason, R. P.; Lawson, N. M.; Sheu, G. R. Mercury in the Atlantic Ocean: factors controlling air-sea exchange of mercury and its distribution in the upper waters. Deep Sea Res., Part II 2001, 48, 2829-2853.

(12) Morel, F. M. M.; Kraepiel, A. M. L.; Amyot, M. The chemical cycle and bioaccumulation of mercury. Annu. Rev. Ecol. Syst. 1998, 29, 543-566.

(13) Fitzgerald, W. F.; Lamborg, C. H.; Hammerschmidt, C. R. Marine biogeochemical cycling of mercury. Chem. Rev. 2007, 107, 641-662.

(14) Alberts, J. J.; Schindler, J. E.; Miller, R. W. Elemental mercury evolution mediated by humic acid. Science 1974, 184, 895-897.

(15) Allard, B.; Arsenie, I. Abiotic reduction of mercury by humic substances in aquatic systems - an important process for the mercury cycle. Water, Air, Soil Pollut. 1991, 56, 457-464. 
(16) Siciliano, S. D.; O’Driscoll, N.; Lean, D. R. D. Microbial reduction and oxidation of mercury in freshwater lakes. Environ. Sci. Technol. 2002, 36, 3064-3068.

(17) Tseng, C. M.; Lamborg, C.; Fitzgerald, W. F.; Engstrom, D. R. Cycling of dissolved elemental mercury in Arctic Alaskan lakes. Geochim. Cosmochim. Acta 2004, 68, 1173-1184.

(18) Garcia, E.; Amyot, M.; Ariya, P. Relationship between DOC photochemistry and mercury redox transformation in temperate lakes and wetlands. Geochim. Cosmochim. Acta 2005, 69, 1917-1924.

(19) Garcia, E.; Poulain, A. J.; Amyot, M.; Ariya, P. A. Diel variations in photoinduced oxidation of $\mathrm{Hg}^{0}$ in freshwater. Chemosphere 2005, 59, 977-981.

(20) Kirk, J. L.; Louis, V. L. S.; Sharp, M. J. Rapid reduction and reemission of mercury deposited into snowpacks during atmospheric mercury depletion events at Churchill, Manitoba, Canada. Environ. Sci. Technol. 2006, 40, 7590-7596.

(21) Monperrus, M.; Tessier, E.; Amouroux, D.; Leynaert, A.; Huonnic, P.; Donard, O. F. X. Mercury methylation, demethylation and reduction rates in coastal and marine surface waters of the Mediterranean Sea. Mar. Chem. 2007, 107, 49-63.

(22) Poulain, A. J.; Garcia, E.; Amyot, M.; Campbell, P. G. C.; Raofie, F.; Ariya, P. A. Biological and chemical redox transformations of mercury in fresh and salt waters of the high arctic during spring and summer. Environ. Sci. Technol. 2007, 41, 1883-1888.

(23) Poulain, A. J.; NíChadhain, S. M.; Ariya, P. A.; Amyot, M.; Garcia, E.; Campbell, P. G. C.; Zylstra, G. J.; Barkay, T. Potential for mercury reduction by microbes in the High Arctic. Appl. Environ. Microbiol. 2007, 73, 2230-2238.

(24) Deng, L.; Fu, D.; Deng, N. Photo-induced transformations of mercury(II) species in the presence of algae, Chlorella vulgaris. $J$. Hazard. Mater. 2009, 164, 798-805.

(25) Wiatrowski, H. A.; Das, S.; Kukkadapu, R.; Ilton, E. S.; Barkay, T.; Yee, N. Reduction of $\mathrm{Hg}(\mathrm{II})$ to $\mathrm{Hg}(0)$ by magnetite. Environ. Sci. Technol. 2009, 43, 5307-5313.

(26) Gu, B. H.; Bian, Y. R.; Miller, C. L.; Dong, W. M.; Jiang, X.; Liang, L. Y. Mercury reduction and complexation by natural organic matter in anoxic environments. Proc. Natl. Acad. Sci. U. S. A. 2011, 108 , $1479-1483$.

(27) Zheng, W.; Liang, L. Y.; Gu, B. H. Mercury reduction and oxidation by reduced natural organic matter in anoxic environments. Environ. Sci. Technol. 2012, 46, 292-299.

(28) Fu, X.; Feng, X.; Yin, R; Zhang, H. Diurnal variations of total mercury, reactive mercury, and dissolved gaseous mercury concentrations and water/air mercury flux in warm and cold seasons from freshwaters of southwestern China. Environ. Toxicol. Chem. 2013, 32, 2256-2265

(29) Hu, H. Y.; Lin, H.; Zheng, W.; Tomanicek, S. J.; Johs, A.; Feng, X. B.; Elias, D. A.; Liang, L. Y.; Gu, B. H. Oxidation and methylation of dissolved elemental mercury by anaerobic bacteria. Nat. Geosci. 2013, $6,751-754$

(30) Mann, E. A.; Mallory, M. L.; Ziegler, S. E.; Tordon, R.; O'Driscoll, N. J. Mercury in Arctic snow: Quantifying the kinetics of photochemical oxidation and reduction. Sci. Total Environ. 2015, 509$510,115-132$.

(31) Grégoire, D. S.; Poulain, A. J. A physiological role for $\mathrm{Hg}^{\mathrm{II}}$ during phototrophic growth. Nat. Geosci. 2016, DOI: 10.1038/ ngeo2629.

(32) O’Driscoll, N. J.; Lean, D. R. S.; Loseto, L. L.; Carignan, R.; Siciliano, S. D. Effect of dissolved organic carbon on the photoproduction of dissolved gaseous mercury in lakes: potential impacts of forestry. Environ. Sci. Technol. 2004, 38, 2664-2672.

(33) Ci, Z. J.; Zhang, X. S.; Wang, Z. W.; Wang, C. J. Mass balance of mercury for the Yellow Sea downwind and downstream of East Asia: the preliminary results, uncertainties and future research priorities. Biogeochemistry 2014, 118, 243-255.

(34) O’Driscoll, N. J.; Siciliano, S. D.; Lean, D. R. S.; Amyot, M. Gross photoreduction kinetics of mercury in temperate freshwater lakes and rivers: application to a general model of DGM dynamics. Environ. Sci. Technol. 2006, 40, 837-843.
(35) Amyot, M.; Lean, D.; Mierle, G. Photochemical formation of volatile mercury in high Arctic lakes. Environ. Toxicol. Chem. 1997, 16, 2054-2063.

(36) Vost, E. E.; Amyot, M.; O’Driscoll, N. J. Photoreactions of mercury in aquatic systems. In Environmental Chemistry and Toxicology of Mercury, Chapter 6; Liu, G. L., Cai, Y., O’Driscoll, N., Eds,; Wiley, 2012.

(37) Soerensen, A. L.; Sunderland, E. M.; Holmes, C. D.; Jacob, D. J.; Yantosca, R. M.; Skov, H.; Christensen, J. H.; Strode, S. A.; Mason, R. P. An improved global model for air-sea exchange of mercury: high concentrations over the North Atlantic. Environ. Sci. Technol. 2010, 44, $8574-8580$

(38) Zhang, Y. X.; Jacob, D. J.; Dutkiewicz, S.; Amos, H. M.; Long, M. S.; Sunderland, E. M. Biogeochemical drivers of the fate of riverine mercury discharged to the global and Arctic oceans. Global Biogeochem. Cy. 2015, 29, 854-864.

(39) Lalonde, J. D.; Amyot, M.; Orvoine, J.; Morel, F. M. M.; Auclair, J.; Ariya, P. A. Photoinduced oxidation of $\mathrm{HgO}(\mathrm{aq})$ in the waters from the St. Lawrence estuary. Environ. Sci. Technol. 2004, 38, 508-514.

(40) Krivan, V.; Haas, H. F. Prevention of loss of mercury(II) during storage of dilute solutions in various containers. Fresenius' $Z$. Anal. Chem. 1988, 332, 1-6.

(41) Ci, Z. J.; Zhang, X. S.; Wang, Z. W.; Niu, Z. C. Phase speciation of mercury $(\mathrm{Hg})$ in coastal water of the Yellow Sea, China. Mar. Chem. 2011, 126, 250-255.

(42) O’Driscoll, N. J.; Beauchamp, S.; Siciliano, S. D.; Rencz, A. N.; Lean, D. R. S. Continuous analysis of dissolved gaseous mercury (DGM) and mercury flux in two freshwater lakes in Kejimkujik Park, Nova Scotia: Examining flux models with quantitative data. Environ. Sci. Technol. 2003, 37, 2226-2235.

(43) USEPA. Method 1631, Revision E: Mercury in Water by Oxidation, Purge and Trap, And Cold Vapor Atomic Fluorescence Spectrometry, EPA-821-R-02-019; Washington, D.C. 2002.

(44) Liou K. N. An introduction to Atmospheric Radiation; Academic Press, 2002.

(45) Amyot, M.; McQueen, D. J.; Mierle, G.; Lean, D. R. S. Sunlightinduced formation of dissolved gaseous mercury in lake waters. Environ. Sci. Technol. 1994, 28, 2366-2371.

(46) Lalonde, J. D.; Amyot, M.; Doyon, M.; Auclair, J. Photo-induced $\mathrm{Hg}$ (II) reduction in snow from the remote and temperate Experimental Lakes Area (Ontario, Canada). J. Geophys. Res. 2003, 108,4200 .

(47) Ci, Z. J.; Zhang, X. S.; Wang, Z. W. Elemental mercury in coastal seawater of Yellow Sea, China: Temporal variation and air-sea exchange. Atmos. Environ. 2011, 45, 183-190.

(48) Ci, Z. J.; Zhang, X. S.; Wang, Z. W.; Niu, Z. C.; Diao, X. Y.; Wang, S. W. Distribution and air-sea exchange of mercury $(\mathrm{Hg})$ in the Yellow Sea. Atmos. Chem. Phys. 2011, 11, 2881-2892.

(49) Ci, Z. J.; Wang, C. J.; Wang, Z. W.; Zhang, X. S. Elemental mercury $(\mathrm{Hg}(0))$ in air and surface waters of the Yellow Sea during late spring and late fall 2012: Concentration, spatial-temporal distribution and air/sea flux. Chemosphere 2015, 119, 199-208.

(50) Fu, X.; Feng, X.; Zhang, G.; Xu, W.; Li, X.; Yao, H.; Liang, P.; Li, J.; Sommar, J.; Yin, R; Liu, N. Mercury in the marine boundary layer and seawater of the South China Sea: Concentrations, sea/air flux, and implication for land outflow. J. Geophys. Res. 2010, 115, D06303.

(51) Tseng, C. M.; Lamborg, C. H.; Hsu, S. C. A unique seasonal pattern in dissolved elemental mercury in the South China Sea, a tropical and monsoon-dominated marginal sea. Geophys. Res. Lett. 2013, 40, 167-172.

(52) Mason, R. P.; Sullivan, K. A. The distribution and speciation of mercury in the South and Equatorial Atlantic. Deep Sea Res., Part II 1999, 46, 937-956.

(53) Soerensen, A. L.; Mason, R. P.; Balcom, P. H.; Sunderland, E. $M$. Drivers of surface ocean mercury concentrations and air-sea exchange in the West Atlantic Ocean. Environ. Sci. Technol. 2013, 47, $7757-7765$.

(54) Qureshi, A.; Macleod, M.; Sunderland, E.; Hungerbuhler, K. Exchange of elemental mercury between the oceans and the 
atmosphere. In Environmental Chemistry and Toxicology of Mercury, Chapter 12; Liu, G. L., Cai, Y., O’Driscoll, N., Eds.; Wiley, 2012.

(55) Bloom, N. S.; Moretto, L. M.; Ugo, P. A. Comparison of the speciation and fate of mercury in two contaminated coastal marine ecosystems: The Venice Lagoon (Italy) and Lavaca Bay (Texas). Limnol. Oceanogr. 2005, 49, 367-375.

(56) Ravichandran, M. Interactions between mercury and dissolved organic matters - A review. Chemosphere 2004, 55, 319-331.

(57) Conaway, C. H.; Squire, S.; Mason, R. P.; Flegal, A. R. Mercury speciation in the San Francisco Bay estuary. Mar. Chem. 2003, 80, 199-225.

(58) Balcom, P. H.; Fitzgerald, W. F.; Vandal, G. M.; Lamborg, C. H.; Rolfhus, K. R.; Langer, C. S.; Hammerschmidt, C. R. Mercury sources and cycling in the Connecticut River and Long Island Sound. Mar. Chem. 2004, 90, 53-74.

(59) Rolfhus, K. R.; Fitzgerald, W. F. Mechanisms and temporal variability of dissolved gaseous mercury production in coastal seawater. Mar. Chem. 2004, 90, 125-136.

(60) Poulain, A. J.; Amyot, M.; Findlay, D.; Telor, S.; Barkay, T.; Hintelmann, H. Biological and photochemical production of dissolved gaseous mercury in a boreal lake. Limnol. Oceanogr. 2004, 49, 22652275.

(61) Brazeau, M. L.; Blais, J. M.; Paterson, A. M.; Keller, W.; Poulain, A. J. Evidence for microbially mediated production of elemental mercury $\left(\mathrm{Hg}^{0}\right)$ in subarctic lake sediments. Appl. Geochem. 2013, 37, $142-148$.

(62) Grégoire, D. S.; Poulain, A. J. A little bit of light goes a long way: the role of phototrophs on mercury cycling. Metallomics 2014, 6, 396407.

(63) Amirbahman, A.; Kent, D. B.; Curtis, G. P.; Marvin-Dipasquale, M. C. Kinetics of homogeneous and surface-catalyzed mercury(II) reduction by iron(II). Environ. Sci. Technol. 2013, 47, 7204-7213.

(64) Fantozzi, L.; Ferrara, R.; Frontini, F. P.; Dini, F. Factors influencing the daily behaviour of dissolved gaseous mercury concentration in the Mediterranean Sea. Mar. Chem. 2007, 107, 4-12.

(65) Yamamoto, M. Stimulation of elemental mercury oxidation in the presence of chloride ion in aquatic environments. Chemosphere 1996, 32, 1217-1224.

(66) Lalonde, J. D.; Amyot, M.; Kraepiel, A. M.; Morel, F. M. Photooxidation of $\mathrm{Hg}(0)$ in artificial and natural waters. Environ. Sci. Technol. 2001, 35, 4961-4961.

(67) Lindberg, S. E.; Vette, A. F.; Miles, C.; Schaedlich, F. Mercury speciation in natural waters: measurement of dissolved gaseous mercury with a field analyzer. Biogeochemistry 2000, 48, 237-259.

(68) Mason, R. P.; Morel, F. M. M.; Hemond, H. F. The role of microorganisms in elemental mercury formation in natural waters. Water, Air, Soil Pollut. 1995, 80, 775-787.

(69) Beucher, C.; Wong-Wah-Chung, P.; Richard, C.; Mailhot, G.; Bolte, M.; Cossa, D. Dissolved gaseous mercury formation under UV irradiation of unamended tropical waters from French Guyana. Sci. Total Environ. 2002, 290, 131-138.

(70) Covelli, S.; Piani, R.; Kotnik, J.; Horvat, M.; Faganeli, J.; Brambati, A. Behaviour of $\mathrm{Hg}$ species in a microtidal deltaic system: the Isonzo River mouth (northern Adriatic Sea). Sci. Total Environ. 2006, 368, 210-223.

(71) Wang, Y. M.; Li, Y. B.; Liu, G. L.; Wang, D. Y.; Jiang, G. B.; Cai, Y. Elemental mercury in natural waters: occurrence and determination of particulate $\mathrm{Hg}(0)$. Environ. Sci. Technol. 2015, 49, 9742-9749. 